\title{
Ekwiwalentność funduszowa i kompensacyjna w systemie zabezpieczenia społecznego - aspekt ubezpieczeniowy
}

Artykuł ${ }^{1}$ prezentuje aspektowe podejście do opisania i wyjaśnienia systemu zabezpieczenia społecznego oraz udział w tym systemie publicznych funduszy socjalnych. Szczególnq uwagę zwraca się na stan publicznych funduszy socjalnych z punktu widzenia ekwiwalentności funduszowej i kompensacyjnej. Na tym tle rozpatruje się możliwości uwzględnienia w systemie zabezpieczenia społecznego rozwiq̨zania nazywanego doubezpieczeniem społecznym, które ma umożliwiać rodzinnym gospodarstwom domowym łatwiejsze osiqganie pożq̨danego poziomu bezpieczeństwa socjalnego poprzez ubezpieczenia prywatne.

Słowa kluczowe: zabezpieczenie społeczne, publiczne fundusze socjalne, ekwiwalentność funduszowa, ekwiwalentność kompensacyjna, ubezpieczenia gospodarstwa domowego.

\section{Wprowadzenie}

Pojęcie ekwiwalentności w systemie zabezpieczenia społecznego, zwłaszcza w publicznych funduszach socjalnych, należy rozpatrywać z dwóch punktów widzenia. Po pierwsze, chodzi o to, co w zakresie finansów publicznych nazywa się gromadzeniem i wydatkowaniem funduszy publicznych, a więc o ekwiwalentność funduszową, określającą stopień zrównoważenia (zbilansowania) konkretnego publicznego funduszu socjalnego, dotyczącego danego ryzyka społecznego. Po drugie, chodzi o to, w jakim stopniu wysokość świadczenia zależy od wcześniej ustalonego wkładu finansowego (daniny publicznej), w postaci składki, składki o charakterze podatkowym czy też podatku, a więc o ekwiwalentność kompensacyjna, określającą stopień (proporcjonalnego czy też nieproporcjonalnego] pokrycia straty świadczeniem w rozpatrywanym zakresie zabezpieczenia społecznego, dotyczącym danego ryzyka społecznego. Podejście takie - właśnie z dwóch

1. Artykuł powstał w wyniku realizacji projektu badawczego $\mathrm{nr}$ 2013/11/B/HS4/02160 finansowanego ze środków Narodowego Centrum Nauki. 
punktów widzenia - pozwala na opisanie i wyjaśnienie tego, jakie konkretne rozwiązania przyjmowane w systemie zabezpieczenia społecznego można uznać za ubezpieczeniowe czy też paraubezpieczeniowe, a jakie - za niespełniające choćby minimalnych zasad zastosowania metody ubezpieczenia w zarządzaniu ryzykiem społecznym.

Opisanie problemu ekwiwalentności w systemie zabezpieczenia społecznego ma podbudować tezę o konieczności rezygnacji ze sposobu myślenia, w którym bezpieczeństwo socjalne jest traktowane jak dobro czysto publiczne, finansowane wyłącznie według zasad gromadzenia i wydatkowania środków publicznych. Wyjaśnienie problemu ekwiwalentności funduszowej i kompensacyjnej jest pretekstem do stwierdzenia, że bezpieczeństwo socjalne trzeba wreszcie uznać za dobro społeczne, za potrzebę, której zaspokojenie wymaga finansowania również ze środków prywatnych.

Tytułowy „aspekt ubezpieczeniowy” należy rozumieć nie tylko jako próbę rozpatrzenia problemu zastosowania ekwiwalentności ubezpieczeniowej w zabezpieczeniu społecznym, ale co ważniejsze - jako zwrócenie uwagi na możliwości rozwoju rynku ubezpieczeniowego poprzez większy w nim udział gospodarstw domowych, motywowanych do zapewnienia sobie wyższego poziomu bezpieczeństwa socjalnego.

Celem artykułu jest bliższe przedstawienie idei i problemów związanych z osiaganiem odpowiedniego poziomu bezpieczeństwa socjalnego przez rodzinne gospodarstwa domowe nie tylko z systemu zabezpieczenia społecznego finansowanego ze środków publicznych, ale też ze środków prywatnych ${ }^{2}$. Tak też powinna być traktowana dodatkowa ochrona ubezpieczeniowa oferowana przez zakłady ubezpieczeń. Trzeba jednak zwrócić uwagę na to, że korzystanie z możliwości podwyższenia poziomu bezpieczeństwa socjalnego poprzez zaangażowanie środków prywatnych powinno być wsparte odpowiednimi formami preferencji o charakterze finansowym, które muszą realistycznie zachęcać do przeznaczania dodatkowych środków na konkretny zakres zabezpieczenia, związany z danym ryzykiem społecznym. Chodzi przy tym o racjonalność rozwiązań preferencyjnych adresowanych przede wszystkim do gospodarstw domowych, ale też kierowanych do pracodawców, udzielających wsparcia finansowego pracownikom w zakresie bezpieczeństwa socjalnego.

Dobrze skonstruowaną, uzupełniającą ochronę ubezpieczeniową, funkcjonującą na zasadach doubezpieczenia społecznego, należałoby uznać za integralną część systemu zabezpieczenia społecznego.

\section{Aspektowy opis i wyjaśnianie systemu zabezpieczenia społecznego}

W opisie i wyjaśnianiu konstrukcji systemu zabezpieczenia społecznego należy zwrócić uwagę na osiem aspektów ${ }^{3}$ :

- celowościowy,

- przedmiotowy,

2. Por. opracowania w: T. Szumlicz, Ubezpieczenie w polityce społecznej. Teksty i komentarze, Fundacja Instytut Zarządzania Ryzykiem Społecznym, Warszawa 2015, s. 157-37?.

3. Wcześniej proponowałem rozważanie pięciu aspektów systemu zabezpieczenia społecznego [T. Szumlicz, 0 systemie zabezpieczenia społecznego - podobnie i inaczej, [w:] O roztropna politykę społecznq, [red.] J. Auleytner, Polskie Towarzystwo Polityki Społecznej, „Śląsk” Wydawnictwo Naukowe, Katowice 2002, s. 122). Później dodałem aspekt legislacyjny (prawny) rozważań, a następnie aspekt celowościowy i aspekt zarządczy, które w obecnej dyskusji o polityce zabezpieczenia społecznego wyraźnie przybierają na znaczeniu (T. Szumlicz, Zabezpieczenie społeczne ... 50 lat później, „Ubezpieczenia Społeczne. Teoria i praktyka” 2016, nr 3, s. 123-139). 
- podmiotowy,

- instrumentalny,

- redystrybucyjny,

- kompensacyjny,

- zarządczy,

- legislacyjny.

Każdy z ośmiu wyróżnionych aspektów można opisywać i wyjaśniać, odnosząc się zarówno do rozważań teoretycznych, jak też rozwiązań praktycznych. Poniżej zarysowano koncepcję podejścia aspektowego do problemu ekwiwalentności funduszowej i ekwiwalentności kompensacyjnej w systemie zabezpieczenia społecznego, najwięcej miejsca poświęcając aspektom: instrumentalnemu, redystrybucyjnemu, kompensacyjnemu i zarządczemu, które dla podjętego problemu maja największe znaczenie.

Aspekt celowościowy wiąże się z odpowiedzią na pytanie zarówno o myśl przewodnią zabezpieczenia społecznego w ogóle, o jego ideę, jak też o podejmowane próby racjonalizowania ${ }^{4}$ syste- $^{-}$ mu zabezpieczenia społecznego. Odpowiadając na te pytania, można przyjać, że przedstawianie problemów zabezpieczenia społecznego powinno być poprzedzone jasnym sformułowaniem jego celu w postaci przyjętego zakresu bezpieczeństwa socjalnego, wynikającego z wziętych pod uwagę ryzyk społecznych zagrażających różnym typom gospodarstw domowych. Przyjmijmy zatem, że system zabezpieczenia społecznego stanowi sieć rozwiązań o charakterze społecznym, ekonomicznym i prawnym, tworzonych przez państwo w celu zapewnienia gospodarstwom domowym ustalonego standardu bezpieczeństwa socjalnego ${ }^{5}$. Chodzi oczywiście o urządzanie systemu zabezpieczenia społecznego skutecznego i efektywnego.

Aspekt przedmiotowy wiąże się z odpowiedzią na pytanie, przed skutkami zaistnienia jakich ryzyk powinien chronić (zabezpieczać) system. Najogólniej chodzi o zdefiniowanie pojęcia ryzyka społecznego na tle pojęcia bezpieczeństwa socjalnego. Dookreślenie „społeczne” (a nie „socjalne” ${ }^{\text {] }}$ do terminu „ryzyko” jest ważne, gdyż powinny interesować nas te ryzyka socjalne, które są uznawane za społeczne, a więc takie, których ranga społeczna jest na tyle wysoka, aby

4. Chodzi o elementy „celowego zakresu” kształtowania: uzasadnianie, wyjaśnianie i usprawnianie (T. Szumlicz, Modele polityki społecznej, Oficyna Wydawnicza SGH, Warszawa 1994, s. 16).

5. Należy zwrócić uwagę na historyczne już stwierdzenie, że zabezpieczenie społeczne ma dwa zakresy, węższy i szerszy. Zakres węższy jest wyznaczony zespołem realnie istniejących instytucji konwencjonalnie zaliczanych do zabezpieczenia społecznego. Zakres szerszy wyznaczają potrzeby ekonomiczne, społeczne i kulturalne, których zaspokojenie przez działalność publiczna jest społecznie uznane za uzasadnione i niezbędne (J. Piotrowski, Zabezpieczenie społeczne. Problematyka i metody, Książka i Wiedza, Warszawa 1966, s. 249-250). Podobne podejście do zabezpieczenia społecznego proponował później M. Księżopolski, odróżniając bezpieczeństwo socjalne i bezpieczeństwo społeczne (zob. M. Księżopolski, Bezpieczeństwo społeczne i jego zagrożenia, [w:] Polityka społeczna w okresie przemian, [red.] A. Piekara, J. Supińska, Państwowe Wydawnictwo Ekonomiczne, Warszawa 1985, s. 20 oraz M. Księżopolski, Zabezpieczenie społeczne, [w:] Nauka o polityce społecznej. Wybrane problemy teorii i praktyki, [red.] J. Auleytner, Instytut Polityki Społecznej UW, Warszawa 1990, s. 109-116). Jednakże stale najpewniejszym tropem dla określenia idei zabezpieczenia społecznego pozostaje to węższe rozumienie „poczucia” bezpieczeństwa socjalnego (A. Rajkiewicz, Zabezpieczenie społeczne, ubezpieczenia i uzupełniajqce świadczenia socjalne, [w:] Polityka społeczna, wydanie III zmienione, [red.] A. Rajkiewicz, Państwowe Wydawnictwo Ekonomiczne, Warszawa 1979, s. 433).

6. Por. J. Jończyk, Prawo zabezpieczenia społecznego, wydanie III uaktualnione, Kantor Wydawniczy Zakamycze, Kraków 2006, s. 13-14. 
objąć je systemowym zabezpieczeniem społecznym. Z kolei dookreślenie „socjalne” przy terminie „bezpieczeństwo” jest ważne, gdyż powinien interesować nas ten zakres bezpieczeństwa, który daje się objąć konwencjonalnym systemem zabezpieczenia społecznego.

Konsekwentnie proponuję definicję ryzyka społecznego (socjalnego) o wyraźnie wyrażonym jego sensie ekonomicznym. Wtedy ryzyko społeczne to zagrożenie zdarzeniem, którego zaistnienie powoduje stratę w posiadanych lub spodziewanych zasobach rodzinnego gospodarstwa domowego? . Definicja ta nawiązuje w szczególności do logiki income security (zabezpieczenia dochodu) wyrażonej w zaleceniu Międzynarodowej Organizacji Pracy z 1944 roku. ${ }^{8}$ Tym niemniej wielokrotnie postulowałem też szersze rozumienie ryzyka w odniesieniu do rodzinnego gospodarstwa domowego, uwzględniające charakter zagrożenia i pojęcia straty ${ }^{9} \mathrm{w}$ zasobach gospodarstwa domowego. Sugerowałem mianowicie poszerzanie zakresu zabezpieczenia społecznego o niektóre ryzyka dotyczące interesu majątkowego sensu stricto, z reguły obejmowanego ochroną ubezpieczeniowa przez prywatne zakłady ubezpieczen ${ }^{10}$. Włączenie tego rodzaju ryzyk do systemu zabezpieczenia społecznego proponuję jednak uzależniać od uznania zastosowanej ochrony ubezpieczeniowej za doubezpieczenie społeczne ${ }^{11}$, o którym będzie dalej.

7. T. Szumlicz, „Szkoła” ubezpieczenia społecznego - założenia teoretyczne i konsekwencje praktyczne, Szkoła Główna Handlowa, Kolegium Ekonomiczno-Społeczne, Katedra Ubezpieczenia Społecznego, Warszawa listopad 2001 (materiał powielony), s. 8.

8. Recommendation No. 67 "Income Security”, [w:] IL0, Convention and Recommendation 1919-1966, Geneva 1966, s. 461-476, a także Recommendation No. 69 „Medical Care”, [w:] IL0, Convention..., s. 480-491. Warto w tym miejscu odnotować odmienne stanowisko K. Krzeczkowskiego jeszcze z 1936 roku, podkreślające z jednej strony - problem utraty środków utrzymania (w zaleceniu MOP problem zabezpieczenia dochodów), ale - z drugiej strony - konieczność scalenia (unifikacji) systemu ubezpieczeń społecznych (K. Krzeczkowski, Idee przewodnie ubezpieczeń społecznych, Instytut Spraw Społecznych, Warszawa 1936), czyli jednak nierozpatrywania zabezpieczenia z punktu widzenia poszczególnych ryzyk społecznych.

9. Tutaj ważny wydaje się też komentarz do ubezpieczeniowej klasyfikacji ryzyk na finansowe i niefinansowe, podziału utożsamianego z charakterem strat wywołanych przez zaistnienie danego ryzyka, gdyż niestety w tej sprawie występuje zasadnicze nieporozumienie. Otóż trzeba konsekwentnie przyjąć, że zdefiniowanie ryzyka jako zagrożenia, którego zaistnienie spowoduje stratę w zasobach, oznacza wyrażenie tej straty w kategoriach finansowych: kosztu, braku lub zmniejszenia zysku (dochodu) itp. Co więcej, takie rozumowanie dotyczy też wyrażania skutków ryzyk osobowych, nawet ryzyka dożycia określonego wieku. Prawdziwsze jest stwierdzenie, że skutek pojawienia się ryzyka może mieć charakter również niefinansowy. Na przykład śmierć żywiciela ma z jednej strony charakter stricte finansowy, gdyż pozbawia gospodarstwo domowe dotychczasowych dochodów i powoduje wydatek w postaci kosztów pogrzebu. Z drugiej strony, jest to utrata bardzo bliskiej osoby. Można zatem stwierdzić, że ryzyko finansowe odnosi się w tym przypadku do (rodzinnego) gospodarstwa domowego, a ryzyko niefinansowe można odnieść do rodziny i osób związanych ze sobą emocjonalnie (T. Szumlicz, Pojęcie ryzyka społecznego i ubezpieczenie gospodarstwa domowego, [w:] Ryzyko ubezpieczeniowe. Wybrane zagadnienia teorii i praktyki, [red.] M. Serwach, Wydawnictwo Uniwersytetu Łódzkiego, Łódź 2013, s. 45-70).

10. Uwzględnienie w zabezpieczeniu społecznym ubezpieczeń prywatnych („ubezpieczenia osobowe i majątkowe ludności"] było proponowane już wcześniej, w ramach przedmiotowego podejścia do określania zakresu zabezpieczenia społecznego, obok: ochrony zdrowia, ubezpieczenia społecznego, pomocy społecznej, rehabilitacji inwalidów, uzupełniających świadczeń socjalnych (A. Rajkiewicz, op. cit., s. 432). Więcej na ten temat: T. Szumlicz, 0 szerszym spojrzeniu na ryzyka o charakterze społecznym, [w:] Ubezpieczenia we współczesnym świecie. Problemy i tendencje, [red.] I. Kwiecień, Wydawnictwo Uniwersytetu Ekonomicznego we Wrocławiu, Wrocław 2017, s. 214-226.

11. Zastosowanie preferencji podatkowych dla skorzystania z ochrony prywatnej. Więcej: ibidem, s. 139-145. 
Przyjmijmy, że punktem wyjścia podejmowanych niżej rozważań powinien być klasyczny katalog ryzyk społecznych ${ }^{12}$, wynikający z zaleceń Międzynarodowej Organizacji Pracy ${ }^{13}$, który obejmuje:

- ryzyko choroby,

- ryzyko macierzyństwa,

- ryzyko inwalidztwa (niezdolności do pracy),

- ryzyko śmierci żywiciela,

- ryzyko wypadku przy pracy,

- ryzyko bezrobocia,

- ryzyko starości,

- ryzyko nagłego wydatku14.

Aspekt podmiotowy wiąże się z odpowiedzią na pytanie o to, kogo ma obejmować system zabezpieczenia społecznego, czy też kto powinien być adresatem wynikających z niego świadczeń. Za objęte systemem zabezpieczenia społecznego ${ }^{15}$ na zasadzie afiliacji lub obowiązku można uznać osoby posiadające status obywatela ${ }^{16}$. Innym ustaleniem kręgu podmiotowego w systemie zabezpieczenia społecznego jest członkostwo w danej (ubezpieczeniowej lub celowej) wspólnocie ryzyka. Możemy też mówić o wspólnotach ryzyka, które w zabezpieczeniu społecznym mogą mieć charakter lokalny czy zawodowy. Natomiast zwracając uwagę na podmiotowość z punktu widzenia cech ewentualnych świadczeniobiorców, wyróżnimy uczestników systemu zabezpieczenia społecznego przede wszystkim ze względu na rodzaj zdarzenia, sytuację rodzinna, status materialny, potrzebę wsparcia. W określaniu podmiotowości uwzględnia się zatem aspekty socjologiczne, ekonomiczne, prawne, a nawet - polityczne.

Jeżeli konsekwentnie mówimy o zabezpieczeniu przed zagrożeniem, którego zaistnienie powoduje stratę, to rzeczywistym podmiotem zabezpieczenia społecznego jest gospodarstwo domowe o danym składzie osobowym. Należy przy tym podkreślić, że pod względem podmiotowym (w sensie wspólnoty ekonomicznej) szczególnie wyróżnia się gospodarstwo domowe, którego funkcjonowanie jest oparte na więziach rodzinnych, gdyż w sensie abstrakcyjnym jego zasobami dysponują wszyscy jego członkowie. Trzeba przy tym zwrócić uwagę, że to rodzinne gospodarstwo domowe ponosi jakieś koszty ochrony (m.in. podatki, składki, środki własne), które zawsze obciążają budżet całego gospodarstwa domowego, a nie są wydatkami jego poszczególnych członków. Natomiast ewentualne świadczenia czynią beneficjentem uzyskanego zabezpieczenia gospodarstwo

12. Ryzyko społeczne jako jedna z najważniejszych kategorii polityki społecznej stanowi kategorię konstrukcyjną w jednym z wyróżnianych przeze mnie modeli polityki społecznej (dokładniejsze omówienie: T. Szumlicz, Modele ..., s. 70-76).

13. ILO, Recommendation No. 67 ... i ILO, Recommendation No. 69...

14. Systemem zabezpieczenia społecznego bywa obejmowane też ryzyko niedołęstwa starczego (wówczas od tego ryzyka „uwalnia się” ryzyko choroby lub ryzyko starości]. Ważnym zagrożeniem jest również obejmowane systemem zabezpieczenia społecznego ryzyko niedostatku, które może wynikać ze skumulowania się skutków innych ryzyk. Interpretacja rozszerzająca zabezpieczenia społecznego - zwłaszcza, gdy chodzi o opisanie i wyjaśnianie rozwiązań o charakterze ubezpieczeniowym - powinna wynikać z zaproponowanej definicji ryzyka społecznego. Wtedy do katalogu ryzyk społecznych należałoby wprowadzić ryzyko nagłego braku jako ogólnie wyrażonego zagrożenia dla różnego rodzaju zasobów majątkowych gospodarstwa domowego: utraty mienia i rzeczy oraz uszczupleń interesu majątkowego. Ryzyko odpowiedzialności cywilnej w życiu prywatnym należałoby jednak uwzględniać w ryzyku nagłego wydatku, a nie braku. Więcej na ten temat T. Szumlicz, Ubezpieczenie społeczne - teoria dla praktyki, Oficyna Wydawnicza Branta, Bydgoszcz-Warszawa 2005, s. 80-81.

15. Również tylko pewnym jego zakresem.

16. Jeszcze raz należałoby podkreślić, że niektóre elementy systemu mogą dotyczyć tzw. rezydentów. 
domowe, ponieważ stają się składnikiem jego budżetu i służą zaspokajaniu potrzeby bezpieczeństwa socjalnego, którym zainteresowane jest gospodarstwo domowe jako określona wspólnota.

Aspekt instrumentalny wiąże się z odpowiedzią na pytanie, jakie zasady (metody i techniki) zabezpieczenia zastosować w systemie. Niezwykle ważnym kryterium w opisaniu i wyjaśnieniu aspektu instrumentalnego jest metoda finansowania zabezpieczenia społecznego, czyli źródło finansowania i rodzaj funduszu gromadzonego w wyznaczonym celu. Trzeba przy tym zwrócić uwagę na wynikający z rodzaju funduszu charakter uprawnień (tytułu) do świadczeń.

Można wyróżnić cztery modelowe zasady zabezpieczenia społecznego, właśnie na podstawie metody finansowania i charakteru uprawnienia do świadczenia. Są to ${ }^{17}$ :

\section{- zasada zaopatrzeniowa,}

- zasada paraubezpieczeniowa ${ }^{18}$,

- zasada ubezpieczeniowa,

\section{- zasada filantropijna.}

W przypadku zasady zaopatrzeniowej chodzi o finansowanie zabezpieczenia z funduszy budżetowych, powstających z podatków. Z zasady tej wynika uprawnienie, które można określić mianem obywatelskiego ${ }^{19}$.W przypadku zasady paraubezpieczeniowej chodzi o finansowanie z publicznych funduszy socjalnych, powstających ze składek o charakterze podatkowym ${ }^{20}$. Z zasady tej wynika uprawnienie członka celowej wspólnoty ryzyka. W przypadku zasady ubezpieczeniowej chodzi o finansowanie zabezpieczenia z funduszy ubezpieczeniowych, powstajacych ze składek ${ }^{21}$. Z zasady tej wynika uprawnienie członka ubezpieczeniowej wspólnoty ryzyka. W przypadku zasady filantropijnej chodzi o finansowanie zabezpieczenia z funduszy charytatywnych, powstających z darowizn. Z tą zasadą wiąże się możliwość otrzymania wsparcia społecznego (z reguły za pośrednictwem pozarządowych organizacji pomocowych).

Do powyższych zasad zabezpieczenia społecznego można by postulować dopisanie zasady indywidualistycznej polegajacej na finansowaniu zabezpieczenia społecznego z funduszy prywatnych. Z zasady tej wynikałoby uprawnienie do świadczeń będące konsekwencją zawarcia

17. Por. T. Szumlicz, 0 systemie zabezpieczenia społecznego ..., s. 124 oraz T. Szumlicz, Publiczne fundusze socjalne - istota oraz organizacja i funkcjonowanie w Polsce, „Studia z Polityki Publicznej” 2014, nr 1, s. 81-100. Zob. zwłaszcza uzasadnienia dla posługiwania się publicznymi funduszami socjalnymi.

18. Przedrostek „para-”, wyrażający równocześnie podobieństwo i zaprzeczenie, wydaje się tutaj odpowiedni, biorąc pod uwagę charakter odstępstw od metody czysto ubezpieczeniowej. Za poprawne można by uznać złożenie dwuwyrazowe „ubezpieczenie społeczne”, ale pod warunkiem konsekwentnego zastosowania minimalnych cech i wymogów rozwiązania ubezpieczeniowego.

19. Tak rozumiane uprawnienie bywa rozszerzane na tzw. rezydentów i członków wspólnot społeczno-ekonomiczno-politycznych, czego dobitnym przykładem są uprawnienia socjalne obywateli Unii Europejskiej (np. Europejska Karta Ubezpieczenia Zdrowotnego).

20. „Składka” w znaczeniu wkładu, udziału (ang. contribution). Należy odnotować, że może być ona płacona przez objętego zabezpieczeniem albo finansowana lub dofinansowywana na rzecz objętego zabezpieczeniem. Można tutaj powtórzyć, że w języku polskim posługujemy się tylko jednym terminem „składka”, podczas gdy w języku angielskim występują dwa terminy premium, kiedy mówimy o ubezpieczeniu, w którym ma zastosowanie składka underwritingowa, o wysokości uzależnionej od ryzyka wnoszonego do ubezpieczeniowej wspólnoty ryzyka, oraz contribution, kiedy mówimy o „ubezpieczeniu”, w którym „składka” oznacza de facto wkład (udział), co może oznaczać różnicowanie tej szczególnej daniny w zależności od statusu materialnego osoby korzystającej z danego zabezpieczenia przed ryzykiem.

21. "Składka” w znaczeniu aktuarialnym i wynikająca z underwritingu ubezpieczeniowego (ang. premium). 
prywatnego kontraktu o charakterze socjalnym. Trzeba jednak zauważyć, że takie modelowe rozwiązanie musi zakładać obowiązek posiadania odpowiedniego zabezpieczenia i - zatem - poniesienia obowiązkowego wydatku (składki) na za-/ubezpieczenie. Można sobie wyobrazić, że czysto prywatne obowiązkowe kontrakty socjalne w formie ochrony ubezpieczeniowej, zapewniające określony zakres bezpieczeństwa socjalnego, mogłyby być oferowane przez zakłady ubezpieczeń ${ }^{22}$.

Aspekt redystrybucyjny wiąże się z odpowiedzią na pytanie, jakie ustalić reguły partycypacji finansowej w systemie zabezpieczenia społecznego. Niewątpliwie ma to związek z zakresem solidaryzmu, który - co trzeba mocno podkreślić - powinien być w poszczególnych podsystemach zabezpieczenia społecznego wyraźnie różnicowany. Problem polega na tym, że choćby finansowanie zabezpieczenia zdrowotnego musi być traktowane inaczej aniżeli finansowanie zabezpieczenie emerytalnego. W pierwszym przypadku, uwzględniając niezbędny solidaryzm dochodowy i bezwzględny solidaryzm ryzyka, trzeba zakładać dużo większy zakres redystrybucji niż w przypadku drugim. Pośrodku tego rozumowania redystrybucyjnego można umieścić sposób finansowania zabezpieczenia na wypadek bezrobocia.

Odwołując się do powyżej opisanych modelowych zasad zabezpieczenia, a w szczególności do wynikających z nich metod finansowania, pożądany zakres redystrybucji dochodów można osiaggać poprzez wybór źródeł finansowania danego zabezpieczenia: z podatków, składek podatkowych, składek ubezpieczeniowych, darowizn, dofinansowań lub środków własnych ${ }^{23}$. Reguły podatkowe, polegające na proporcjonalnie znacznie większym udziale w finansowaniu budżetowym obywateli lepiej sytuowanych, będących w lepszej sytuacji materialnej, zapewniają najwyższy stopień redystrybucji, zwłaszcza gdy w opodatkowaniu stosuje się odpowiednie skale progresywne. Gromadzenie publicznego funduszu socjalnego ze składek podatkowych jest zbliżone do opodatkowania liniowego. Oczywiście inny wymiar redystrybucyjny (redystrybucja losowa) ma gromadzenie ze składek funduszu ubezpieczeniowego, jeszcze inny wymiar redystrybucyjny (redystrybucja dobrowolna) - finansowanie zabezpieczenia z darowizn itd.

Należy przy tym pamiętać, że funkcja redystrybucyjna w zabezpieczeniu społecznym powinna być wykonywana z odpowiednim wyczuciem, nawet jeżeli dotyczy zaspokajania najważniejszych potrzeb społecznych, ponieważ redystrybucji dokonuje się na czyjaś korzyść, ale też czyimś kosztem. Zakres redystrybucji ${ }^{24}$ może być uznawany za mniej lub bardziej sprawiedliwy w zależności od celu danych rozwiązań socjalnych. Oczywiście ważna jest akceptacja społeczna lub przynajmniej przyzwolenie społeczne dotyczące reguł partycypacji finansowej w systemie zabezpieczenia społecznego.

Aspekt kompensacyjny wiąże się z odpowiedzią na pytanie o to, w jakim zakresie system ma pokrywać straty. Otóż o realnej ochronie w ramach zabezpieczenia społecznego decyduje zasada miarkowania kompensaty straty ${ }^{25}$, która zakłada częściowe pokrywanie poniesionych strat. Zakres kompensacji określają wtedy ogólne wskaźniki (stopy) zastapienia, które wyrażaja stosunek przeciętnego świadczenia do przeciętnej straty ${ }^{26}$. Co jednak nadzwyczaj ważne, w zabezpieczeniu

22. W tym przypadku w zakresie zabezpieczenia zdrowotnego mówi się o ubezpieczeniu substytucyjnym.

23. Dlatego też zastosowanie jednolitej daniny w finansowaniu zabezpieczenia społecznego powinno budzić wątpliwości, gdyż nie pozwala na stosowanie odmiennych zasad i różnicowania zakresów redystrybucji.

24. Istotne znaczenie miałoby konsekwentne posługiwanie się wskaźnikami redystrybucji w ubezpieczeniu społecznym (T. Szumlicz, Ubezpieczenie społeczne..., s. 152).

25. Ibidem, s. 114.

26. Najpowszechniej znana jest stopa zastapienia w zabezpieczeniu emerytalnym, ale określenie to dotyczy również innych zakresów zabezpieczenia społecznego. 
społecznym na ogół stosowane jest różnicowanie stopnia kompensacji w zależności od wielkości poniesionej straty. Korzystanie z relatywnie większej ochrony dotyczy gorzej sytuowanych gospodarstw domowych, gdyż kompensata straty w przypadku mniejszej straty jest z reguły relatywnie większa. Korzystanie z relatywnie mniejszej ochrony dotyczy lepiej sytuowanych gospodarstw domowych, gdyż kompensata straty w przypadku większej straty jest z reguły relatywnie mniejsza.

Istotne jest zatem nie tylko pytanie o ogólny zakres kompensowania strat w ramach systemu zabezpieczenia społecznego, lecz także o skalę nieproporcjonalności w kompensowaniu strat, o zasadność i konsekwencje stosowania swoistej redystrybucji dokonywanej po stronie ustalania świadczeń2?

Aspekt zarządczy wiąże się z odpowiedzią na pytanie, jakie instytucje publiczne lub prywatne powinny czy też mogą być włączane w organizację i funkcjonowanie systemu zabezpieczenia społecznego z punktu widzenia skutecznej i efektywnej realizacji jego celu. Przede wszystkim chodzi o sprawność występujących w systemie wyspecjalizowanych instytucji publicznych. Należy jednak zwrócić uwagę na to, że państwo może angażować do realizacji zadań z zakresu swoich funkcji socjalnych, w tym przypadku zabezpieczenia społecznego, podmioty prywatne. Wówczas można mówić o publiczno-prywatnym zarządzaniu (administrowaniu) systemem zabezpieczenia społecznego, o uzupełnianiu systemu instytucjami prywatnymi, włączanymi do zarządzania środkami publicznymi. Trzeba jednak w tym miejscu zauważyć, że zarządzanie systemem zabezpieczenia społecznego wiąże się z wyraźna odpowiedzialnością państwa, wynikającą albo ze stosunku władczego nad instytucjami publicznymi, albo z nadzoru nad działalnością instytucji prywatnych, poprzedzanego zresztą koncesjonowaniem działalności. W pierwszym przypadku (stosunku władczego) szczególnym problemem jest niezbędna decentralizacja zarzadzania. W obu przypadkach - bo dotyczy to zarówno instytucji publicznych, jak i prywatnych - nadzwyczaj ważne jest uzyskanie zaufania społecznego do przyjmowanych zarządczych rozwiązań instytucjonalnych w zakresie zabezpieczenia społecznego ${ }^{28}$.

Aspekt legislacyjny wiąże się z odpowiedzią na pytanie, jak w praktyce powinno być stanowione i stosowane prawo dotyczące rozwiązań systemowych w zakresie zabezpieczenia społecznego. W kształtowaniu i usprawnianiu procesu legislacyjnego nie da się przecenić problemu wprowadzania do polskiego porządku prawnego regulacji wynikających z dostosowywania krajowych rozwiązań w zakresie zabezpieczenia społecznego do standardów międzynarodowych i uzgodnień unijnych, w tym przepisów o charakterze koordynacyjnym w ramach Unii Europejskiej ${ }^{29}$.

27. Więcej: ibidem, s. $145-152$.

28. Udział w systemie zabezpieczenia społecznego instytucji prywatnych należałoby rozpatrywać, odpowiadając na pytanie, czy są one zdolne skutecznie i efektywnie wykonywać dane zadania społeczne, mimo ich komercyjnych zasad funkcjonowania. Udział w systemie zabezpieczenia społecznego instytucji prywatnych jest niestety często kojarzony ze „skokiem na publiczną kasę”, a nie racjonalizowaniem tego systemu.

29. T. Bińczycka-Majewska, Zasady koordynacji systemów zabezpieczenia społecznego w Unii Europejskiej, [w:] Europejskie prawo pracy i ubezpieczeń społecznych, [red.] L. Florek, Warszawa: Instytut Pracy i Spraw Socjalnych 1997, s. 246-277; M. Żukowski, Otwarta koordynacja zabezpieczenia emerytalnego w Unii Europejskiej - nowy etap europejskiej polityki społecznej, „Polityka Społeczna” 2002, nr 11-12, s. 44-47; G. Uścińska, Europejskie standardy zabezpieczenia społecznego a współczesne rozwiqzania polskie, Instytut Pracy i Spraw Socjalnych, Warszawa 2005, s. 36-42; J. Jończyk, Prawo zabezpieczenia ..., s. 32-37; K. Hagemejer, Podstawowe gwarancje zabezpieczenia społecznego - praktyka, koncepcja, standard i globalna polityka społeczna, „Polityka Społeczna” 2013, nr 11-12. 
Na tle powyższego wywodu stwierdzenie, że każda polityka społeczna wiąże się z pewnym zakresem redystrybucji dochodów ${ }^{30}$, gdyż taki jest finansowy sens (aspekt, wymiar) solidaryzmu społecznego, wynikającego z przyjętych założeń tej polityki, okazuje się zbyt ogólne. Dotyczy to też realizowanej (prowadzonej), postulowanej lub deklarowane ${ }^{31}$ polityki zabezpieczenia społecznego. Ważne są bowiem ostateczne formy, jakie przybieraja procesy wtórnego podziału dochodów dokonujące się za pośrednictwem różnorodnych danin publicznych. Przyjmijmy zatem, że to w działaniach odnoszących się do opisanych aspektów instrumentalnego, redystrybucyjnego i kompensacyjnego zabezpieczenia społecznego „ukryte” są odmienne formy i mechanizmy, decydujące - z jednej strony - o relatywnie mniejszym lub większym udziale obywateli (de facto poszczególnych gospodarstw domowych) w finansowaniu zabezpieczenia społecznego, a z drugiej strony - o relatywnie mniejszym lub większym poziomie zaspokajania potrzeby społecznej, jakajest bezpieczeństwo socjalne. W szczególności chodzi o możliwość zweryfikowania pod tym względem tych konstrukcji, które przynajmniej z założenia - można traktować jako publiczne fundusze socjalne.

\section{Publiczne fundusze socjalne - problem ekwiwalentności}

Definiując publiczne fundusze socjalne ${ }^{32}$, należy się odwołać do pojęcia „publicznych funduszy celowych" jako szczególnej formy gromadzenia i wydatkowania środków publicznych ${ }^{33}$. W opisie publicznego funduszu celowego ${ }^{34}$ podkreśla się, że powstanie funduszu oznacza wyodrębnienie finansowe i organizacyjne części pieniężnych środków publicznych z ogółu środków publicznych oraz przekazanie ich do dyspozycji danych gestorów. Oznacza to związanie części środków publicznych z wyznaczonymi zadaniami, zapewnienie źródeł finansowania wybranej dziedziny działalności, co podnosi jej rangę wśród wszystkich obowiązków władz publicznych. Powinno to zapewniać swoistą niezależność i ciagłość finansowania oraz rezerwową kumulację środków niewykorzystanych, jednak trzeba dodać - co bardzo ważne dla dalszego wywodu - iż taka swoboda dysponowania środkami jest realna pod warunkiem, że wykonywanie zadań nie wymaga dotacji z budżetu państwa.

Analizując przesłanki tworzenia publicznych funduszy celowych oraz posługiwania się nimi w praktyce, przywołuje się ich ważne funkcje ${ }^{35}$ :

- alokacji środków publicznych,

- redystrybucji dochodów,

- mobilizacji środków publicznych,

- racjonalizacji wydatków publicznych,

podkreślając, że w przypadku pierwszej funkcji chodzi o administracyjny mechanizm alokacji, a drugiej - o redystrybucję dochodów z założenia przymusową (te dwie funkcje co do zasady

30. T. Szumlicz, O modelach polityki społecznej i pożqdanej redystrybucji dochodów, [w: W Wokół polityki społecznej, [red.] K. Głąbicka, M. Grewiński, Polskie Towarzystwo Polityki Społecznej, Warszawa 2008, s. 85-100.

31. Warto zwracać uwagę na to rozróżnienie (T. Szumlicz, Modele ..., s. 8).

32. Więcej: T. Szumlicz, Publiczne fundusze socjalne ..., s. 81-100.

33. S. Owsiak, Finanse publiczne. Teoria i praktyka, wydanie drugie, uaktualnione, Wydawnictwo Naukowe PWN, Warszawa 1999, s. 130-136.

34. Ibidem, s. 130-131.

35. Ibidem, s. 131-132. 
są realizowane analogicznie jak przez budżet państwa). Równocześnie zwraca się uwagę na odmienność i istotne znaczenie funkcji mobilizacyjnej, podkreślając aspekt większej z założenia akceptacji społecznej dla celowego obciążenia fiskalnego, a także - funkcji racjonalizacyjnej, gdyż aspekt celowości z założenia osłabia wpływ czynnika politycznego, arbitralności zmiany i woluntaryzmu w ustalaniu hierarchii celów i zadań (w opisie korzyści wynikających z racjonalizacji wydatków publicznych podkreśla się też: możliwość zerwania z zasadạjednoroczności budżetowania, stabilizację dochodów publicznych przez ustawowe ustalenie źródeł finansowania, zapewnienie ciagłości zadań, elastyczne kształtowanie wydatków w zależności od zmieniających się potrzeb).

Po wcześniejszych rozważaniach na temat ryzyka społecznego i ogólnym opisie funkcji funduszy celowych, można stwierdzić, że publiczne fundusze socjalne to różnorodne rodzaje funduszy celowych, tworzonych w związku z danym ryzykiem społecznym, gromadzących według ustalonych zasad publiczne środki pieniężne w celu finansowania konkretnych świadczeń społecznych, udzielanych przez nominowane podmioty publiczne ${ }^{36}$.

Tak więc, w przypadku zasady paraubezpieczeniowej, w systemie zabezpieczenia społecznego usytuowanej między zasadą zaopatrzeniową i zasadą ubezpieczeniową ( w tym zwłaszcza pod względem finansowania podatkowego albo składkowego ${ }^{37}$ ), którą utożsamiamy z organizacja i funkcjonowaniem publicznego funduszu socjalnego, należy zwrócić uwagę na:

- regułę powiązania środków publicznych z danym ryzykiem społecznym (chodzi o ścisłe przypisanie funduszu do danego obszaru zabezpieczenia społecznego, co powinno zapewniać niezależność i ciągłość finansowania, uwzględniającą rezerwową kumulację środków niewykorzystanych),

- zastosowanie ekwiwalentności funduszowej (chodzi o wymóg ekwiwalentności, polegającej na zrównoważeniu sumy składek z sumą świadczeń, a zatem dotacja budżetowa do funduszu może być dopuszczalna tylko w sensie gwarancyjnym i w ustalonym zakresie, natomiast nie należałoby wykluczać techniki kredytowania funduszu),

- charakter uczestnictwa w funduszu (celowa wspólnota ryzyka powinna mieć charakter udziałowy w sensie finansowym, wynikający z obowiązku przystapienia i wnoszenia określonego wkładu finansowego do danego funduszu, niezależnie od tego, czy partycypacja finansowa dotyczy osoby korzystającej z zabezpieczenia, czy też pracodawcy lub wskazanej instytucji),

- rodzaj obciążenia finansowego (powinno być ono ustalane parametrycznie, co oznacza uzależnienie wkładu finansowego od podstawy wymiaru, która może odnosić się do statusu materialnego korzystającego z ochrony, czyli w konsekwencji przyjmować postać podatku liniowego, przy czym nie należy wykluczać zastosowania zryczałtowanego wkładu finansowego),

- założenie dotyczące redystrybucji (chodzi o zastosowanie redystrybucji przymusowej, charakterystycznej dla zasady zaopatrzeniowej i finansowania podatkowego zabezpieczenia, ale równocześnie - redystrybucji losowej, charakterystycznej dla zasady ubezpieczeniowej ${ }^{38}$ ),

36. T. Szumlicz, Publiczne fundusze socjalne ..., s. 90.

37. Pewnej interpretacji teoretycznej i praktycznej tego usytuowania można by dokonać na podstawie wywodu w: P.M. Gaudemet, J. Molinier, Finanse publiczne, Polskie Wydawnictwo Ekonomiczne, Warszawa 2000, s. 417-420, dotyczącego składek na ubezpieczenia społeczne we Francji.

38. Chodzi też o dokładniejsze przyjrzenie się realnym transferom dochodów, które wynikają z tworzenia w ramach systemu zabezpieczenia społecznego publicznych funduszy socjalnych (odpowiedź na pytanie, kto de facto tak skonstruowane przedsięwzięcia społeczne finansuje oraz kto de facto z danych rozwiązań społecznych mniej lub bardziej korzysta], niezależne od faktu występowania takich zjawisk, jak nieracjonalne obciążenia fiskalne i nadużywanie świadczeń społecznych. 
- zasadę uzyskiwania uprawnienia do świadczenia (chodzi o zastosowanie cechy ekwiwalentności świadczenia ubezpieczeniowego, czyli za wymagany wkład finansowy do funduszu zapewniany jest ustalony zakres ochrony],

- zakres kompensacji straty (należy zakładać pewien zakres nieproporcjonalnej kompensaty, polegajacej na zastosowaniu reguły, że mniejsza strata jest kompensowana w relatywnie większym zakresie, a większa strata jest kompensowana w relatywnie mniejszym zakresie, ale należy też ustalić skalę odstępstw od reguły ekwiwalentności kompensacyjnej w zależności od danego ryzyka społecznego],

- podejście zarzạdcze (zarządzanie funduszami może polegać na rozwiązaniach publiczno-prywatnych, pod warunkiem odpowiedniego procesu koncesjonowania i nadzoru nad funkcjonowaniem ze strony nominowanego podmiotu publicznego].

Taki teoretyczny opis i wyjaśnienie organizacji i funkcjonowania publicznych funduszy socjalnych można skonfrontować z rozwiązaniami praktycznymi, w szczególności rozpatrując ich ekwiwalentność funduszową i kompensacyjną.

Otóż należy przyjąc, że w 1999 roku ${ }^{39}$ wyróżnienie podfunduszy ${ }^{40}$ emerytalnego, rentowego, chorobowego i wypadkowego w ramach Funduszu Ubezpieczenia Społecznego (FUS), będącego w dyspozycji Zakładu Ubezpieczeń Społecznych (ZUS), miało zmierzać do ukształtowania prawdziwych publicznych funduszy socjalnych. Trzeba jednak odnotować, że już na wstępie nie spełniały one podstawowego kryterium ich wyodrębniania - przypisania podfunduszu do danego ryzyka społecznego. Tak różne ryzyka, jak niezdolność do pracy i śmierć żywiciela ujęto jednym podfunduszem - rentowym. Jednym podfunduszem ujęto też tak odmienne powody nieświadczenia pracy, jak chorobę i macierzyństwo (zob. schemat 1.).

\section{Schemat 1. Struktura Funduszu Ubezpieczeń Społecznych według ryzyk społecznych}

\begin{tabular}{ll} 
RYZYKA & PODFUNDUSZE \\
\hline Starości & $\begin{array}{l}\text { emerytalny } \\
\text { niezdolności do pracy i śmierci żywiciela } \\
\text { chorowy } \\
\text { choroby i macierzyństwa }\end{array}$ \\
wypadku przy pracy, choroby zawodowej & $\begin{array}{l}\text { wypadkowy } \\
\text { wyong }\end{array}$
\end{tabular}

${ }^{a}$ nieświadczenie pracy z powodu choroby

= FUNDUSZ UBEZPIECZEŃ SPOŁECZNYCH

${ }^{\mathrm{b}}$ nieświadczenie w pracy w okresie urlopu macierzyńskiego

Źródło: oprac. własne.

W praktyce poważniejszym problem jest to, czy publiczne fundusze socjalne spełniają regułę ekwiwalentności funduszowej. Problem braku takiej ekwiwalentności w funkcjonowaniu podfunduszy FUS od początku okazywał się nierozwiązalny. A trzeba zauważyć - co interesujące, choć dzisiaj wydaje się absurdalne - że w ramach FUS w 1999 roku wyodrębniono nawet fundusze rezerwowe: wspólny dla funduszy rentowego i chorobowego, odmienny dla funduszu wypadkowego, a także Fundusz Rezerwy Demograficznej (dla funduszu emerytalnego). Wszystkie one były też opatrzone zapisem, że tworzy się je „ze środków pozostających w dniu 31 grudnia każdego roku

39. Ustawa z dnia 13 października 1998 r. o systemie ubezpieczeń społecznych (Dz. U. 1998, nr 137 poz. 887), art. 55.

40. W ustawie o systemie ubezpieczeń społecznych nie używa się terminu podfundusz, a jego zastosowanie przy podziale FUS czyniłoby zapisy ustawowe bardziej czytelne. 
na rachunku” ... (danego funduszu) ... „pomniejszonych o kwoty niezbędne do zapewnienia wypłat świadczeń przypadających na pierwszy miesiąc kolejnego roku"41.

Najogólniej mówiąc, gromadzenie ze składek podatkowych odpowiedniej wielkości publicznych funduszy socjalnych, zapewnienie ich „ekwiwalentności funduszowej”, stale będzie nierealne (zob. tab. 4.), aczkolwiek w ostatnich latach można zauważyć znaczącą poprawę stopnia zbilansowania podfunduszy (zob. tab. 1.-3.), a prognozy nie przewiduja znacznego pogorszenia stanu podfunduszy. Warto przy tym odnotować, że deficyt nie dotyczy podfunduszu wypadkowego, którego gromadzenie odbywa się z zastosowaniem zmienności składki (ustalanie wysokości składki zbliżone do zasad underwritingu), której wysokość zależy od szkodowości wypadkowej i warunków pracy w danej branży i danym przedsiębiorstwie (dane prognostyczne pozwalałyby zakładać obniżanie składek na podfundusz wypadkowy.

Tabela 1. Ekwiwalentność funduszowa podfunduszy FUS w 2011 roku [w mln zł]

\begin{tabular}{|l|c|c|c|}
\hline \multicolumn{1}{|c|}{ Podfundusze } & Przypis składek [S] & Świadczenia [Ś] & Wskaźnik S/Ś w \% \\
\hline - emerytalny & 63004,3 & 106243,4 & 59,3 \\
\hline - rentowy & 24268,3 & 40232,5 & 60,3 \\
\hline - chorobowy & 10012,2 & 11122,2 & 90,0 \\
\hline - wypadkowy & 6103,4 & 5123,1 & 119,1 \\
\hline FUS razem & 103388,2 & 162721,2 & 63,5 \\
\hline
\end{tabular}

Źródło: oprac. własne na podst. danych Departamentu Statystyki i Prognoz Aktuarialnych ZUS.

Tabela 2. Ekwiwalentność funduszowa podfunduszy FUS w 2016 roku ( $w$ mln zł)

\begin{tabular}{|l|c|c|c|}
\hline \multicolumn{1}{|c|}{ Podfundusze } & Przypis składek [S] & Świadczenia [Ś] & Wskaźnik S/Ś w \% \\
\hline - emerytalny & 93889,6 & 131080,8 & 71,6 \\
\hline - rentowy & 40491,9 & 45486,7 & 89,0 \\
\hline - chorobowy & 12116,5 & 19988,1 & 60,6 \\
\hline - wypadkowy & 6704,8 & 5054,6 & 132,6 \\
\hline FUS razem & 153202,8 & 201610,4 & 76,0 \\
\hline
\end{tabular}

Źródło: oprac. własne na podst. danych Departamentu Statystyki i Prognoz Aktuarialnych ZUS.

Tabela 3. Prognoza ekwiwalentności funduszowej podfunduszy FUS dla roku 2017 ( $w \mathrm{mln}$ zł)

\begin{tabular}{|l|c|c|c|}
\hline \multicolumn{1}{|c|}{ Podfundusze } & Przypis składek [S] & Świadczenia [Ś) & Wskaźnik S/Ś w \% \\
\hline - emerytalny & 99899 & 142436 & 70,1 \\
\hline - rentowy & 41492 & 48208 & 86,1 \\
\hline - chorobowy & 12260 & 20837 & 58,8 \\
\hline - wypadkowy & 6881 & 5344 & 128,8 \\
\hline FUS razem & 160532 & 216825 & 74,0 \\
\hline
\end{tabular}

Źródło: oprac. własne na podst.: Prognoza wpływów i wydatków funduszu ubezpieczeń społecznych na lata 20172021, Zakład Ubezpieczeń Społecznych, Departament Statystyki i Prognoz Aktuarialnych, Warszawa grudzień 2015 (kwoty niezdyskontowane stopą inflacji; wariant średni pod względem wydolności FUS).

41. Art. 55-58 ustawy z dnia 13 października 1998 r. o systemie ubezpieczeń społecznych (Dz.U. 1998, nr 137 poz. 887). 
Tabela 4. Prognoza ekwiwalentności funduszowej podfunduszy FUS dla roku 2021 ( $w \mathrm{mln}$ zł)

\begin{tabular}{|l|c|c|c|}
\hline \multicolumn{1}{|c|}{ Podfundusze } & Przypis składek (S) & Świadczenia [Ś) & Wskaźnik S/Ś w \% \\
\hline - emerytalny & 123717 & 180824 & 68,4 \\
\hline - rentowy & 51537 & 55643 & 92,6 \\
\hline - chorobowy & 15219 & 25600 & 59,4 \\
\hline - wypadkowy & 8540 & 5646 & 151,3 \\
\hline FUS razem & 199013 & 267713 & 74,3 \\
\hline
\end{tabular}

Źródło: oprac. własne na podst.: Prognoza wpływów i wydatków... (kwoty niezdyskontowane stopą inflacji; wariant średni pod względem wydolności FUS).

Nie analizując szczegółowo przyczyn braku ekwiwalentności funduszowej, z pewnością innych dla poszczególnych podfunduszy, można stwierdzić, że nie ma obecnie szansy na znaczące poprawienie wskaźników pokrycia świadczeń (Ś) przez przypis składek (S) ${ }^{42}$. Tolerowanie nieekwiwalentności funduszowej w przypadku podfunduszy emerytalnego, rentowego i chorobowego można nawet nazwać rozwiązaniem „systemowym”. Niezbilansowanie jest dopuszczalne i w zasadzie akceptowane, mimo że wiąże się z koniecznością systematycznych dopłat gwarancyjnych do podfunduszy z budżetu państwa. Inaczej trzeba by rozważyć daleko idące zmiany albo po stronie gromadzenia środków, albo po stronie wypłat świadczeń, co byłoby raczej nierealistycznym przedsięwzięciem natury politycznej ${ }^{43}$. Na marginesie można odnotować, że obecne dopłaty do FUS z budżetu są rozwiązaniem bardziej redystrybucyjnym niż ewentualne rozwiązanie, jakim byłoby podwyższenie składek podatkowych.

Po zarysowaniu problemu ekwiwalentności funduszowej, przejdźmy do omówienia nie mniej ważnego problemu ekwiwalentności kompensacyjnej, czyli relacji między wkładem finansowym a świadczeniem. Właśnie podejście do tej formuły ekwiwalentności w publicznych funduszach socjalnych okazuje się szczególnie interesujące. Po pierwsze, dlatego że stosowane są rozwiązania zachowujące - przynajmniej pozornie - ekwiwalentność kompensacyjną. Po drugie, dlatego że wprowadzane odstępstwa od ekwiwalentności kompensacyjnej można rozważać od strony udziału finansowego, gdy wkłady finansowe do funduszu są różnicowane (uzależnione od usytuowania materialnego), albo od strony świadczenia, gdy wysokości świadczeń są różnicowane [uzależnione od wysokości straty. ${ }^{44}$. Po trzecie, dlatego że niezwykle istotne jest uzasadnianie zakresu odstępstw od ekwiwalentności kompensacyjnej.

Można podać dwa przykłady, gdy polski system zabezpieczenia społecznego w zasadzie zapewnia ekwiwalentność kompensacyjna. Pierwszy - dotyczy zabezpieczenia zdrowotnego, związanego z ryzykiem choroby uniemożliwiającej świadczenie pracy (strata dochodu z pracy powodowana choroba). Wtedy bowiem wkład finansowy do podfunduszu chorobowego FUS zależy od uzyskiwanego wynagrodzenia a zasiłek chorobowy jest proporcjonalny do utraconego wynagrodzenia. Drugi - dotyczy zabezpieczenia emerytalnego, w którym późniejsze świadczenie emerytalne ma

42. Relacja ta w: Prognoza wpływów i wydatków... nazywana jest wydolnością (iloraz wpływów i wydatków).

43. Dobrym na to dowodem była nieudana próba ujednolicenia daniny publicznej, co w swoisty sposób mogło tylko ukryć niezrównoważenie publicznych funduszy socjalnych.

44. Można rozważać zastosowanie nieekwiwalentności równocześnie od strony udziału finansowego i od strony wysokości świadczenia. 
być uzależnione od wcześniej zapłaconych składek, czyli systemu zabezpieczenia emerytalnego funkcjonującego według zasady zdefiniowanej składki (pomijamy tu nieekwiwalentność wynikającą ze sposobu liczenia tzw. kapitału początkowego i dopłat do emerytur minimalnych] ${ }^{45}$.

Ważniejsze dla prowadzonego wywodu jest jednak zwrócenie uwagi na te rozwiązania w systemie zabezpieczenia społecznego i publicznych funduszach socjalnych, w których stosuje się - mniej lub bardziej uzasadnione - odstępstwa od ekwiwalentności kompensacyjnej.

Nie wchodząc w szczegóły poszczególnych rozwiązań niezachowujących ekwiwalentności kompensacyjnej, trzeba odróżniać przynajmniej dwie sytuacje. Pierwszą, w której nieekwiwalentność występuje wyraźnie po stronie wkładu finansowego, można przedstawić na przykładzie systemu zabezpieczenia zdrowotnego, związanego z ryzykiem choroby w postaci uszczerbku na zdrowiu (ewentualna strata powodowana koniecznością pokrycia kosztów leczenia). Rozwiązanie systemowe polega wtedy na zróżnicowaniu wysokości wkładu finansowego na Narodowy Fundusz Zdrowia (NFZ), który zależy od uzyskiwanego wynagrodzenia ${ }^{46}$ (jeżeli w ogóle taki wkład jest wymagany ${ }^{47}$, to jest wyższy od osób o wyższych dochodach i niższy od osób o niższych dochodach, a więc w mniejszym stopniu obciąża budżety gorzej sytuowanych gospodarstw domowych), ale uprawnienia do świadczeń sa jednakowe (wynikają z przyjętego koszyka gwarantowanych świadczeń zdrowotnych $]^{48}$. Drugą sytuację, w której nieekwiwalentność występuje wyraźnie po stronie świadczenia, można zobrazować przykładem zabezpieczenia rentowego, związanego z ryzykiem śmierci żywiciela (ewentualna strata w budżecie gospodarstwa domowego powodowana brakiem dochodów z pracy wcześniej uzyskiwanych przez zmarłego członka tego gospodarstwa). Wkład finansowy do podfunduszu rentowego FUS zależy w tym przypadku od uzyskiwanego wynagrodzenia (jest niższy od osób o niższych wynagrodzeniach i wyższy od osób o wyższych wynagrodzeniach), co można uznać za zachowanie ekwiwalentności od strony gromadzenia funduszu, gdyż można mówić o zróżnicowaniu wkładu finansowego od ryzyka mniejszej lub większej straty. Jednakże ewentualne świadczenie rentowe nie jest wypłacane ekwiwalentnie, gdyż jest relatywnie większe przy mniejszej stracie (renta rodzinna jest relatywnie większa, gdy utracone wynagrodzenie było mniejsze), a relatywnie mniejsze przy większej stracie (renta rodzinna jest relatywnie mniejsza, gdy utracone wynagrodzenie było większe).

Najogólniej mówiąc, są to przykłady na to, że od gospodarstw domowych gorzej sytuowanych oczekuje się mniejszego wkładu finansowego do systemu zabezpieczenia społecznego, ale równocześnie zapewniany jest im relatywnie wyższy poziom bezpieczeństwa socjalnego. Z relatywnie mniejszej ochrony korzystaja gospodarstwa domowe lepiej sytuowane, gdyż kompensacja strat w przypadku większej straty jest z reguły relatywnie mniejsza. Obrazowo przedstawia to schemat 2., który jednak inaczej wygląda dla gospodarstw domowych o niższym i wyższym statusie

45. Pewne zastrzeżenia co do występowania ekwiwalentności kompensacyjnej w obu wymienionych sytuacjach można by też formułować ze względu na przymus udziału w zabezpieczeniu, ale obowiązkowość dotyczy wielu ubezpieczeń prywatnych, w których występowanie ekwiwalentności kompensacyjnej nie jest raczej podważane.

46. Dotyczy to zarówno części składki odpisywanej, jak i nieodpisywanej od podatku.

47. Udział w systemie bez finansowego wkładu, opłacania tzw. składek.

48. W zabezpieczeniu zdrowotnym - przy korzystaniu z tego samego zakresu świadczeń - można zastosować też finansowanie w postaci wkładu zryczałtowanego albo składki, której wysokość zależałaby od ryzyka wyrażanego choćby wiekiem ubezpieczonego. Również w takich rozwiązaniach nieekwiwalentność kompensacyjna dotyczyłaby wkładu finansowego, ale w innych, bardziej czytelnych zakresach. 
materialnym. Jeżeli przyjać, że chodzi o uzupełnienie różnicy między wysokością dotychczasowego dochodu (przyjmijmy, że jest to pożądany standard zabezpieczenia) a wysokością świadczenia otrzymywanego z FUS (istniejacy standard zabezpieczenia), to relatywnie większe pole do wypełnienia prywatną ochroną ubezpieczeniową maja gospodarstwa domowe o wyższym statusie materialnym niż gospodarstwa domowe o niższym statusie materialnym ${ }^{49}$.

\section{Schemat 2. Powstawanie pola dla uzupełniającego zabezpieczenia społecznego $\mathrm{w}$ formie ochrony ubezpieczeniowej}

pożądany standard zabezpieczenia

40 uzupełniajaca ochrona ubezpieczeniowa

istniejący standard zabezpieczenia

Źródło: oprac. własne.

Niezupełnie na marginesie, trzeba jednak w tym miejscu zauważyć diametralną zmianę dokonaną w zabezpieczeniu emerytalnym (z systemu o zdefiniowanym świadczeniu na system o zdefiniowanej składce), bardzo niekorzystna dla gospodarstw domowych o niższym statusie materialnym. Otóż osoby o niższych wynagrodzeniach sukcesywnie przestają korzystać z uprzywilejowania, w postaci wyższych wskaźników zastapienia wynagrodzenia emerytura, wynikajacego ze sposobu (przyjętego wzoru) obliczania świadczeń emerytalnych w starym systemie o zdefiniowanym świadczeniu ${ }^{50}$. Podkreślona sukcesywność wynika z tego, że osoby urodzone po 31 grudnia 1948 roku nabywaja prawo do emerytury w zasadzie według nowych reguł (świadczenie zależy od wielkości uprawnień repartycyjnych i kapitałowych nabywanych z zapłaconych składek oraz przeciętnego dalszego trwania życia], jednakże stale ważny element posiadanych uprawnień w postaci tzw. kapitału początkowego (uprawnień wynikających z udziału w starym systemie, obliczanych według zasad zdefiniowanego świadczenia), „buforuje” drastyczny spadek stóp zastapienia osiaganych przez osoby o niższych wynagrodzeniach ${ }^{51}$.

Podsumowując, z teoretycznego punktu widzenia w przypadku podfunduszy FUS trudno jest mówić o prawdziwych publicznych funduszach socjalnych ${ }^{52}$. Są one ze względu na ryzyka społeczne skonstruowane niekonsekwentnie, widoczne jest ich niezbilansowanie, z też tego powodu nie można mówić o ich niezależności i ciągłości finansowania, a tym bardziej o tworzeniu dla nich funduszy rezerwowych, z powodu oczywistej nierealności kumulacji środków niewykorzystanych ${ }^{53}$. Wymóg ekwiwalentności funduszowej, polegającej na zrównoważeniu sumy składek z sumą świadczeń, jest niewykonalny, a zbilansowanie finansowania jest osiagane wyłącznie

49. Zob. T. Szumlicz, Ubezpieczenie społeczne ..., s. 146-153.

50. Ibidem, s. $147-149$.

51. Ibidem, s. 260.

52. Wcześniej nie wykluczałem jednak, że wnikliwsze spojrzenie na zasady finansowania systemu zabezpieczenia społecznego, który ma chronić przed skutkami zaistnienia danego ryzyka społecznego, zapewniając określony standard bezpieczeństwa socjalnego, pozwala przyją́ teoretyczne założenie o możliwości zastosowania w systemie zabezpieczenia społecznego rozwiązań w postaci publicznych funduszy socjalnych (T. Szumlicz, Publiczne fundusze socjalne..., s. 81-100.

53. Zresztą nie czyni się tego nawet w odniesieniu do podfunduszu wypadkowego, przeznaczając nadwyżki środków z ubezpieczenia wypadkowego na niewielkie pokrywanie deficytów w pozostałych podfunduszach. 
przez dotacje budżetowe, z cała pewnością przekraczające ich charakter nadzwyczajny, stricte gwarancyjny. Dochodzi do tego problem nie tyle braku ekwiwalentności kompensacyjnej, gdyż jest to w przypadku zabezpieczenia społecznego uzasadnione, ile ustalenia pożądanego zakresu zróżnicowania ekwiwalentności kompensacyjnej, w ramach poszczególnych publicznych funduszy socjalnych związanych z danymi ryzykami społecznymi.

Takie pesymistyczne podsumowanie wywodu nie powinno oznaczać przekreślenia możliwości posługiwania się przez państwo, w sprawowaniu jego funkcji socjalnej, odpowiednio skonstruowanymi publicznymi funduszami socjalnymi. Ich ewentualnego wykorzystania w racjonalizowaniu finansów publicznych, a przede wszystkim systemu zabezpieczenia społecznego, nie można bowiem przecenić, chociaż organizacja i funkcjonowanie systemu zabezpieczenia społecznego pokazuje, że jesteśmy dalecy od przestrzegania w tym systemie opisanej wyżej zasady paraubezpieczeniowej.

\section{O paradygmacie doubezpieczenia społecznego i rozwoju rynku ubezpieczeniowego}

Nie podważając ogólnej zasady, że środki występujące w różnych formach danin publicznych muszą dominować w finansowaniu systemu zabezpieczenia społecznego, a także zwracając uwagę na to, że konieczne jest racjonalizowanie gromadzenia i wydatkowania tych środków, można w tym miejscu sformułować istotne zastrzeżenie związane z realnym finansowaniem bezpieczeństwa socjalnego. Chodzi o to, że bezpieczeństwo socjalne nie powinno być traktowane jak czyste dobro publiczne, finansowane ze środków publicznych ${ }^{54}$. Bezpieczeństwo socjalne trzeba uznawać za dobro społeczne, którego zaspokojenie musi w jakiejś mierze uwzględniać angażowanie dodatkowych środków prywatnych przez gospodarstwa domowe i zakłady pracy na rzecz zatrudnionych. Finansowanie zabezpieczenia społecznego ze środków prywatnych (nie tylko pochodzących z darowizn], należy zatem wspierać.

W tym miejscu zasadnicze znaczenie ma następujące ogólne stwierdzenie: jeżeli państwo nie jest w stanie zapewnić odpowiedniego poziomu bezpieczeństwa socjalnego, to nie powinno opodatkowywać wydatków ponoszonych przez gospodarstwa domowe w celu podniesienia tego poziomu.

Taka teza ideowa, którą staram się upowszechniać w publikacjach i wystapieniach konferencyjnych od prawie dziesięciu lat ${ }^{55}$, ma szczególne znaczenie dla zmiany systemu zabezpieczenia społecznego, dokonywanej ze względu na uwarunkowania demograficzne, finansowe czy świadomościowe. Niestety fiskus reaguje na taką tezę raczej niechętnie, widząc w niej przede wszystkim zagrożenia dla budżetu państwa. Tymczasem rzeczywisty problem polega na trudnościach w utrzymaniu dotychczasowego - i tak niezbyt wysokiego - poziomu bezpieczeństwa socjalnego, przy zwiększającym się udziale środków publicznych.

54. Zob. rozróżnienie stosowane w ramach finansów publicznych na czyste dobra publiczne i dobra społeczne (S. Owsiak, Finanse publiczne..., s. 26-28).

55. Zob. np. T. Szumlicz, Reforma Indywidualnych Kont Emerytalnych, [w:] Zabezpieczenie społeczne w Polsce. Problemy do rozwiqzania w najbliższej przyszłości, [red.] G. Uścińska, Instytut Pracy i Spraw Socjalnych, Warszawa 2008, s. 147; T. Szumlicz, Społeczno-ekonomiczne znaczenie III filara systemu emerytalnego, [w:] Rola rynku ubezpieczeniowego w realizacji reformy systemu emerytalnego, [red.] T. Szumlicz, „Wiadomości Ubezpieczeniowe" marzec 2008 - wydanie specjalne, s. 72. 
Należy przyjąć, że problem dobrowolnego korzystania z ochrony ubezpieczeniowej wiąże się z pojęciami „doubezpieczenia” i „doubezpieczenia społecznego”. Jednakże w systemie zabezpieczenia społecznego powinno występować „doubezpieczenie społeczne”, którego cechą odróżniajacą od „doubezpieczenia” są preferencje (zachęty) przede wszystkim, ale nie tylko, o charakterze finansowym wyraźnie adresowane do gospodarstw domowych ${ }^{56}$.

Doubezpieczenie społeczne to zatem uzupełniająca wobec bazowego systemu zabezpieczenia społecznego - dodatkowa ochrona ubezpieczeniowa, objęta konkretnymi preferencjami (zachętami], służąca podniesieniu standardu bezpieczeństwa socjalnego, który rozpatrywany jest z punktu widzenia rodzinnych gospodarstw domowych. Za doubezpieczenie społeczne, stanowiące uzupełniającą część systemu zabezpieczenia społecznego, nie należy uznawać korzystania przez gospodarstwa domowe z produktów finansowych, ubezpieczeń prywatnych itp., których zakup nie jest poparty konkretnymi preferencjami społecznymi (wtedy mówimy tylko o doubezpieczeniu).

Takie ujęcie definicyjne można uzupełnić kilkoma komentarzami ${ }^{5 ?}$.

Otóż punktem odniesienia dla pojęcia doubezpieczenia społecznego jest bazowa część systemu zabezpieczenia społecznego (ubezpieczeń społecznych, publicznych funduszy socjalnych) ${ }^{58}$, który ma zapewniać tylko podstawowy standard bezpieczeństwa socjalnego. 0 wyższy poziom bezpieczeństwa socjalnego swoich członków powinno zadbać przede wszystkim (rodzinne) gospodarstwo domowe ${ }^{59}$, jednakże dostatecznie do tego motywowane. Trzeba przy tym zauważyć, że poszczególne typy gospodarstw domowych, w zależności przede wszystkim od swojego statusu materialnego, korzystają ze zróżnicowanego standardu bezpieczeństwa socjalnego, uzyskiwanego z systemu ubezpieczenia społecznego. Pojawia się zatem problem adekwatnego do potrzeb ${ }^{60}$ wykorzystania możliwego doubezpieczenia społecznego, które uwzględniałoby również dokonywane zmiany w systemie zabezpieczenia społecznego.

Pojęcie doubezpieczenia społecznego należy traktować również funkcjonalnie, a nie tylko produktowo. Ważny jest bowiem system stosowanych rozwiązań i preferencji społecznych (ich adresaci, zakres, skala, formy), który stanowi realne uwarunkowania dla zakupu odpowiednich produktów ubezpieczeniowych zapewniajacych wyższy poziom bezpieczeństwa socjalnego. Konkretne rozwiązania i preferencje moga być mniej lub bardziej wyraźnym sygnałem tego, że państwo jako organizator systemu zabezpieczenia społecznego oczekuje decyzji gospodarstw domowych podejmowanych w tym celu.

56. Więcej T. Szumlicz, Ubezpieczenie społeczne ..., s. 139 i nast.

57. Por. ibidem, s. 140-142.

58. Doubezpieczamy się do czegoś, z czego możemy już korzystać.

59. Nie można też wykluczać udziału pracodawców w organizowaniu ochrony ubezpieczeniowej dla swoich pracowników i ich rodzin. Inicjatywy pracodawców będą miały jednak znaczenie drugorzędne.

60. Wchodzi tutaj w grę również subiektywne, indywidualne podejście do pożądanego standardu zabezpieczenia emerytalnego. W rozważaniach dotyczących zarządzania ryzykiem gospodarstwa domowego istotne jest odniesienie do klasyfikacji ryzyka na subiektywne i obiektywne. Ryzyko obiektywne istnieje niezależnie od zdolności percepcyjnych czy innych cech podmiotu podejmującego decyzję. Z kolei ryzyko subiektywne jest określane z reguły jako niepewność oparta na doświadczeniach osobistych lub nastroju duchowym. Z całą pewnością można powiedzieć, że ryzyko subiektywne jest indywidualną oceną istnienia ryzyka i oceną szansy zaistnienia straty. Można w tej sprawie przywołać tekst E. Kowalewskiego (E. Kowalewski, Przyczynek do behawioralnej teorii ryzyka, [w:] Społeczne aspekty ubezpieczenia, [red.] T. Szumlicz, Oficyna Wydawnicza SGH, Warszawa 2005, s. 11 i nast. Postrzeganie i ocena ryzyka przez rodzinne gospodarstwo domowe ma wpływ również na sposób postępowania wobec ryzyka społecznego, a więc też na realne uczestnictwo w doubezpieczeniu społecznym. 
Problem doubezpieczenia społecznego występuje oczywiście niezależnie od zastosowanych zasad (zaopatrzeniowych, paraubezpieczeniowych, filantropijnych) w konstrukcji bazowego systemu zabezpieczenia społecznego. Jednakże należy podkreślić, że nazwę „doubezpieczenie” należy wywodzić z charakteru ochrony dodatkowej stosowanej w zarządzaniu ryzykiem, czyli z metody ubezpieczenia. Ochronę ubezpieczeniowa przed skutkami ryzyk społecznych należy bowiem uznać za najbardziej skuteczną i efektywną z punktu widzenia uzyskania pełniejszego bezpieczeństwa socjalnego.

Zmian w kierunku pożądanego poziomu bezpieczeństwa socjalnego nie da się osiagnaác bez poważniejszego potraktowania doubezpieczenia społecznego, doubezpieczenia polegającego na preferencjach społecznych skierowanych do gospodarstw domowych. Chodzi o przede wszystkim preferencje finansowe związane z zakupem prywatnej ochrony ubezpieczeniowej, ale nie mniej ważne są te wynikające z zapewnienia właściwego nadzoru nad rynkiem ubezpieczeniowym, kompetentnego doradztwa ubezpieczeniowego, odpowiedniego zakresu gwarancji dla ochrony ubezpieczeniowej oraz silnej reprezentacji interesów ubezpieczonych, uposażonych i uprawnionych.

Z punktu widzenia omówionych problemów dotyczących ekwiwalentności funduszowej i ekwiwalentności kompensacyjnej publicznych funduszy socjalnych, nie można przecenić rozwiązań społecznych zachęcających rodzinne gospodarstwa domowe do podniesienia standardu bezpieczeństwa socjalnego swoich członków dzięki dodatkowej ochronie ubezpieczeniowej. Preferencje finansowe udzielane gospodarstwom domowym w postaci zwolnień i ulg podatkowych, refinansowania składek, celowych dopłat, należałoby traktować jako swoisty koszt obciążajacy budżet państwa po stronie przychodowej bądź wydatkowej, ale ponoszony dla zracjonalizowania systemu zabezpieczenia społecznego. Doubezpieczenie społeczne, odwołujące się do prywatnej ochrony ubezpieczeniowej, z której korzystanie byłoby objęte konkretnymi preferencjami nie tylko finansowymi, powinno być traktowane jako komplementarne wobec bazowego systemu zabezpieczenia społecznego i uważane za integralny element tego systemu ${ }^{61}$.

W doubezpieczeniu społecznym można by uwzględniać korzystanie z już istniejących produktów ubezpieczeniowych, związanych z ryzykami uszczerbku zdrowia, niezdolności do pracy, śmierci żywiciela, starości, w których zakres ochrony jest wyznaczany na podstawie sum ubezpieczenia odpowiadających swoistej „wycenie” wartości życia i zdrowia ubezpieczonego.

Tym niemniej - na tle całego powyższego wywodu - warta rozważenia byłaby propozycja nowej konstrukcji produktów ubezpieczeniowych, zwłaszcza dotycząca ryzyk niezdolności do pracy i śmierci żywiciela, biorąca pod uwagę: (1) stratę w dochodach gospodarstwa domowego, (2) zakres kompensaty straty uzyskiwanej przez gospodarstwo domowe z publicznego zabezpieczenia społecznego i (3) wysokość świadczenia uzupełniającego zapewniającego pokrycie luki dochodowej w budżecie gospodarstwa domowego (spowodowanej zaistnieniem danego ryzyka społecznego]. Wymagałoby to oczywiście przeprowadzenia odpowiednich rachunków aktuarialnych, które nie wydają się łatwe, chociażby z powodu konieczności uwzględnienia w nich faz cyklu życia i zmienności dochodów ubezpieczonego. Warto jednak zauważyć, że wprowadzenie takich produktów urozmaiciłoby ofertę ubezpieczeń życiowych z punktu widzenia cech jej adresatów (danych gospodarstw domowych), pod względem zakresu ochrony (sprecyzowanie luki

61. Za doubezpieczenie społeczne, stanowiące uzupełniającą część systemu zabezpieczenia społecznego, nie można uznać korzystania przez gospodarstwa domowe z produktów finansowych, w tym zwłaszcza z ubezpieczeń prywatnych, których zakup nie jest poparty konkretnymi preferencjami społecznymi. Wtedy można mówić tylko o doubezpieczeniu w ogóle. 
dochodowej] i ze względu na cenę (niższy koszt ochrony uzupełniającej), a zatem prowadziłoby do niewątpliwie korzystnego rozwoju rynku ubezpieczeniowego pod względem jego struktury, w której bardziej widoczny byłby udział ochrony skierowanej do gospodarstw domowych.

Zakłady ubezpieczeń powinny wykazać większe zainteresowanie tak zdefiniowanym ubezpieczeniem społecznym, które winno polegać na gotowości zaoferowania odpowiedniej oferty produktowej. Wiadomo również, że nie można liczyć na „samodzielną" inicjatywę państwa w tym zakresie. Mówiąc kolokwialnie: trzeba tej inicjatywie pomóc.

Racjonalne podwyższanie poziomu bezpieczeństwa socjalnego poprzez dobrze konstruowana dodatkową ochronę ubezpieczeniową byłaby też szczególnym wyzwaniem dla zakładów ubezpieczeń po wprowadzeniu od 2018 roku ustawy o dystrybucji ubezpieczeń, w której na konieczność dostosowania ochrony ubezpieczeniowej do potrzeb osób jej poszukującej zwraca się nadzwyczajną uwagę.

\section{Zakończenie}

Posługiwanie się w polityce społecznej (ściślej: w systemie zabezpieczenia społecznego, w systemie finansów publicznych) kategoria publicznego funduszu socjalnego powinno się utożsamiać z danym ryzykiem społecznym, gdyż jest to podstawowa przesłanka wyróżniania funduszu ze względu na cel i nadanie mu odpowiedniej rangi.

Ekwiwalentność w systemie zabezpieczenia społecznego, a w szczególności w ramach publicznych funduszy socjalnych, należy rozpatrywać, odwołując się do pojęcia ekwiwalentności ubezpieczeniowej, chociaż w rozwiązaniach paraubezpieczeniowych nie można zakładać występowania bezwzględnej ekwiwalentność funduszowej i wysokiej ekwiwalentności kompensacyjnej.

Szczególną uwagę należy zwrócić na zasady gromadzenia danego funduszu, które - z jednej strony - decyduja o partycypacji finansowej w danych rozwiazaniach, gdyż udział finansowy w funduszu socjalnym jest uzależniony bardziej od statusu materialnego niż od ryzyka, a - z drugiej strony - zasady te mają decydujący wpływ na ostateczną wielkość funduszu, z którego maja być wypłacane należne świadczenia (problem zbilansowania funduszu).

Zasadnicze znaczenie ma konstrukcja świadczeń wypłacanych z konkretnych funduszy socjalnych, w szczególności dotyczy to zakresu kompensowania strat, gdyż kompensacja jest na ogół częściowa i może być nieproporcjonalna (mniejsza strata jest kompensowana w relatywnie większym zakresie, i odwrotnie).

Mimo formalnego przeświadczenia o posługiwaniu się w Polsce państwowymi funduszami celowymi o charakterze socjalnym (świadczeniowym) ${ }^{62}$, należy stwierdzić, że realnych rozwiązań paraubezpieczeniowych występujących w systemie zabezpieczenia społecznego nie można traktować jako publicznych funduszy socjalnych, w ścisłym - zdefiniowanym w tym opracowaniu - znaczeniu. W szczególności trudno mówić o możliwości wykorzystywania funkcji mobilizacyjnej i funkcji racjonalizacyjnej, które powinny zapewniać konstrukcje finansowe typu funduszy celowych. Nie można więc liczyć na akceptację społeczną dla większego celowego obciążenia fiskalnego, a także na osłabienie wpływu czynnika politycznego i ograniczenie arbitralności decyzji,

62. Konkretne państwowe fundusze celowe, związane z zadaniami socjalnymi państwa, są wymieniane w ustawie budżetowej według swego przeznaczenia. 
nie mówiąc już o elastycznym gromadzeniu i wydatkowaniu (odejście od jednoroczności budżetowania] środków publicznych na zabezpieczenie społeczne.

W prowadzonej przez państwo polityce zabezpieczenia społecznego można w większym lub mniejszym stopniu „tolerować” brak ekwiwalentności funduszowej, gromadzenia i wydatkowania środków finansowych. Taka jest też praktyka z powodu trudności we wprowadzaniu zmian, które - najogólniej mówiąc - musiałyby się wiązać albo ze zwiększeniem finansowania albo ze zmniejszeniem kompensaty, a chodzi o obawę braku przyzwolenia społecznego dla zmian zarówno po stronie wkładów finansowych, jak i po stronie wypłaty świadczeń. Nie mniej skomplikowany jest problem ekwiwalentności kompensacyjnej, gdyż przyjęte zakresy pokrycia strat mają zapewniać bezpieczeństwo socjalne w postaci adekwatnych świadczeń. Najogólniej mówiąc, chodzi o to, że rozwiązania zakładające zastosowanie proporcjonalności między wcześniejszym wkładem finansowym a późniejszym świadczeniem mogłyby takich świadczeń nie zapewniać.

Problem uzyskiwania odpowiedniego bezpieczeństwa socjalnego przez rodzinne gospodarstwa domowe zarysowuje się zatem coraz ostrzej, tym bardziej, że zagadnienia ekwiwalentności kompensacyjnej nie da się też rozpatrywać bez kontekstu międzynarodowych standardów zabezpieczenia społecznego ${ }^{63}$.

Na tym tle należy też analizować postulowane zmiany w systemie zabezpieczenia społecznego w Polsce. Na ogół eksponuje się ich powody ekonomiczne (ściślej - finansowe, fiskalne), bardziej skupiając się na ograniczaniu wydatków publicznych niż na zmianie ich struktury i sposobie gromadzenia środków. Najczęściej mówi się o konieczności zreformowania finansów publicznych (ulubione i wyraźnie nadużywane słowo wytrych w dyskusjach na ten temat), nie dostrzegając społecznych przesłanek zmiany systemu, celu i najistotniejszych uwarunkowań. Zasadnicza wydaje się konstatacja, że celem zmiany powinno być racjonalizowanie systemu zabezpieczenia społecznego, a nie powodowanie oszczędności w finansach publicznych, jeżeli nawet okażą się rezultatem wprowadzenia nowych rozwiązań systemowych.

Ważne jest przyjęcie założenia, że finansowanie zabezpieczenia społecznego, w celu uzyskania odpowiedniego poziomu bezpieczeństwa socjalnego, powinno odbywać się nie tylko z funduszy publicznych ( z różnorodnych form danin publicznych), ale też w pewnym zakresie - na zasadach dobrowolności - ze środków prywatnych gospodarstw domowych ${ }^{64}$. Jednakże odwoływanie się do zasady indywidualistycznej, polegającej na finansowaniu zabezpieczenia społecznego z funduszy

63. Zob. G. Uścińska, Międzynarodowe standardy i formy współpracy w polityce społecznej oraz ich wpływ na Polskę, [w:] Polityka społeczna. Podręcznik akademicki, [red.] G. Firlit-Fesnak, M. Szylko-Skoczny, Wydawnictwo Naukowe PWN, Warszawa 2007, s. 163-173.

64. Odrębnym problemem jest zakres obowiązkowego i dobrowolnego udziału pracodawców w tym finansowaniu. 
prywatnych $^{65}$, powinno być rozważane w Polsce jako doubezpieczenie społeczne (różne formy dodatkowego zabezpieczenia ${ }^{66}$ objęte konkretnymi preferencjami].

W prowadzonej przez państwo polityce zabezpieczenia społecznego powinno się poważnie potraktować koncepcję doubezpieczenia społecznego ${ }^{67}$. Winny być tym oczywiście zainteresowane zakłady ubezpieczeń, które - zapewniając prywatną ochronę ubezpieczeniowa - powinny optować za rozwiązaniami publiczno-prywatnymi i proponować ofertę produktową uwzględniającą zróżnicowanie zakresu zabezpieczenia społecznego uzyskiwanego przez rodzinne gospodarstwa domowe w zależności od ich usytuowania w fazach rozwoju i statusu materialnego.

Szczególnie ważne dla racjonalizowania ${ }^{68}$ finansów publicznych są rozważania na temat zabezpieczenia społecznego prowadzone z punktu widzenia rozwiązań publiczno-prywatnych.

Jeżeli o odpowiedni poziom bezpieczeństwa socjalnego powinny zadbać również rodzinne gospodarstwa domowe, dostatecznie do tego motywowane, zwłaszcza finansowo, to niezwykle ważna jest teza, że edukacja finansowa jako proces kształtowania w tym zakresie postaw, wartości, wiedzy i umiejętności musi polegać przede wszystkim na dostarczaniu informacji o zaletach (korzyściach) i wadach (zagrożeniach) istniejących oraz postulowanych rozwiązań, w których realne zachęty finansowe (formy bezpośredniego i pośredniego dofinansowania: dopłaty, refinansowanie, zwolnienia, ulgi itp.) są czy też mają mieć zastosowanie. Inaczej mówiąc, często postulowana edukacja finansowa nie może odbywać się w próżni, czyli nie może zastępować realnych zachęt finansowych do korzystania z doubezpieczenia społecznego.

Zmierzając do upowszechniania rozwiązań, w których o odpowiedni poziom bezpieczeństwa socjalnego mają zabiegać rodzinne gospodarstwa domowe, trzeba zadbać o kształtowanie świadomości ryzyka społecznego i przezorności ubezpieczeniowej, o sprawną komunikację społeczną w tym zakresie, w którą muszą się włączyć także zakłady ubezpieczeń. Pozwoliłoby to zyskiwać pożądaną akceptację społeczna (a przynajmniej przyzwolenie społeczne) dla sukcesywnego wprowadzania do systemu zabezpieczenia społecznego idei doubezpieczenia społecznego.

65. Zastosowanie zasady indywidualistycznej w zabezpieczeniu społecznym jest na ogół doubezpieczeniem (zakupem dodatkowego ubezpieczenia). W zabezpieczeniu zdrowotnym może przybierać niezwykle różnorodne formy: obowiązkowego ubezpieczenia substytucyjnego (rozwiązanie systemowe w Niemczech), ubezpieczenia suplementarnego, abonamentu zdrowotnego, medycznego konta oszczędnościowego, dopłaty do danej usługi zdrowotnej, opłat bezpośrednich za usługi zdrowotne. W zabezpieczeniu rentowym, obejmującym ryzyko niezdolności do pracy i ryzyko śmierci żywiciela, może to być prywatne ubezpieczenie na życie. W zabezpieczeniu emerytalnym, obejmującym ryzyko starości, chodzi o różne formy uzupełniającego oszczędzania emerytalnego i ubezpieczenie emerytalne.

66. Przede wszystkim ochrony ubezpieczeniowej.

67. Warto zwrócić uwagę na publikację promującą ideę doubezpieczenia społecznego i jej kontynuację (Doubezpieczenie społeczne - idea i kontynuacja, [red.] M. Kawiński, Oficyna Wydawnicza SGH, Warszawa 2015).

68. Do wcześniejszego stwierdzenia, iż polityka społeczna jako nauka praktyczna ma formułować postulaty dotyczace racjonalizowania działalności praktycznej, czyli jej uzasadniania, wyjaśniania i usprawniania (T. Szumlicz, Modele ..., 29), można dodać, że „Nowoczesna nauka o finansach publicznych nie ogranicza się do badania gospodarki funduszami publicznymi, lecz wyjaśnia treść ekonomiczną i społeczną funduszy publicznych" (S. Owsiak, Finanse publiczne ..., op. cit., s. 21). 


\section{Wykaz źródeł}

\section{Literatura:}

Bińczycka-Majewska T., Zasady koordynacji systemów zabezpieczenia społecznego w Unii Europejskiej, [w:] Europejskie prawo pracy i ubezpieczeń społecznych, Florek L. [red.], Instytut Pracy i Spraw Socjalnych, Warszawa 1997.

Gaudemet P.M., Molinier J., Finanse publiczne, Polskie Wydawnictwo Ekonomiczne, Warszawa 2000. Hagemejer K., Podstawowe gwarancje zabezpieczenia społecznego - praktyka, koncepcja, standard i globalna polityka społeczna, „Polityka Społeczna” 2013, nr 11-12.

Jończyk J., Prawo zabezpieczenia społecznego, wydanie III uaktualnione, Kantor Wydawniczy Zakamycze, Kraków 2006.

Kawiński M. [red.], Doubezpieczenie społeczne - idea i kontynuacja, Oficyna Wydawnicza SGH, Warszawa 2015.

Kowalewski E., Przyczynek do behawioralnej teorii ryzyka, [w:] Społeczne aspekty ubezpieczenia, Szumlicz T. [red.], Oficyna Wydawnicza SGH, Warszawa 2005.

Krzeczkowski K., Idee przewodnie ubezpieczeń społecznych, Instytut Spraw Społecznych, Warszawa 1936.

Księżopolski M., Bezpieczeństwo społeczne i jego zagrożenia, [w:] Polityka społeczna w okresie przemian, Piekara A., Supińska J. [red.], Państwowe Wydawnictwo Ekonomiczne, Warszawa 1985. Księżopolski M., Zabezpieczenie społeczne, [w:] Nauka o polityce społecznej. Wybrane problemy teorii i praktyki, Auleytner J. [red.], Instytut Polityki Społecznej UW, Warszawa 1990.

Owsiak S., Finanse publiczne. Teoria i praktyka, wydanie drugie, uaktualnione, Wydawnictwo Naukowe PWN, Warszawa 1999.

Prognoza wpływów i wydatków funduszu ubezpieczeń społecznych na lata 2017-2021, Zakład Ubezpieczeń Społecznych, Departament Statystyki i Prognoz Aktuarialnych, Warszawa grudzień 2015.

Rajkiewicz A., Zabezpieczenie społeczne, ubezpieczenia i uzupełniajqce świadczenia socjalne, [w:] Polityka społeczna, wydanie III zmienione, Rajkiewicz A. [red.], Państwowe Wydawnictwo Ekonomiczne, Warszawa 1979.

Recommendation No. 67 „Income Security”, [w:] Convention and Recommendation 1919-1966, International Labour Organisation (ILO), Geneva 1966.

Recommendation No. 69 „Medical Care”, [w:] Convention and Recommendation 1919-1966, International Labour Organisation (ILO), Geneva 1966.

Piotrowski J., Zabezpieczenie społeczne. Problematyka i metody, Książka i Wiedza, Warszawa 1966. Szumlicz T., Modele polityki społecznej, Oficyna Wydawnicza SGH, Warszawa 1994.

Szumlicz T., 0 modelach polityki społecznej i pożqdanej redystrybucji dochodów, [w:] Wokół polityki społecznej, Głąbicka K., Grewiński M. [red.], Polskie Towarzystwo Polityki Społecznej, Warszawa 2008.

Szumlicz T., 0 systemie zabezpieczenia społecznego - podobnie i inaczej, [w:] 0 roztropna politykę społecznq, Auleytner J. [red.], Polskie Towarzystwo Polityki Społecznej, „Śląsk” Wydawnictwo Naukowe, Katowice 2002. 
Szumlicz T., 0 szerszym spojrzeniu na ryzyka o charakterze społecznym, [w:] Ubezpieczenia we współczesnym świecie. Problemy i tendencje, Kwiecień I. [red.], Wydawnictwo Uniwersytetu Ekonomicznego we Wrocławiu, Wrocław 2017.

Szumlicz T., Pojęcie ryzyka społecznego i ubezpieczenie gospodarstwa domowego, [w:] Ryzyko ubezpieczeniowe. Wybrane zagadnienia teorii i praktyki, Serwach M. [red.], Wydawnictwo Uniwersytetu Łódzkiego, Łódź 2013.

Szumlicz T., Publiczne fundusze socjalne - istota oraz organizacja ifunkcjonowanie w Polsce, „Studia z Polityki Publicznej” 2014, nr 1(1).

Szumlicz T., Reforma Indywidualnych Kont Emerytalnych, [w: ] Zabezpieczenie społeczne w Polsce. Problemy do rozwiqzania w najbliższej przyszłości, Uścińska G. [red.], Instytut Pracy i Spraw Socjalnych, Warszawa 2008.

Szumlicz T., Społeczno-ekonomiczne znaczenie III filara systemu emerytalnego, [w:] Rola rynku ubezpieczeniowego w realizacji reformy systemu emerytalnego, Szumlicz T. [red.], „Wiadomości Ubezpieczeniowe" marzec 2008 - wydanie specjalne.

Szumlicz T., „Szkoła” ubezpieczenia społecznego - założenia teoretyczne i konsekwencje praktyczne, Szkoła Główna Handlowa, Kolegium Ekonomiczno-Społeczne, Katedra Ubezpieczenia Społecznego, Warszawa listopad 2001 (materiał powielony).

Szumlicz T., Ubezpieczenie społeczne - teoria dla praktyki, Oficyna Wydawnicza Branta, BydgoszczWarszawa 2005.

Szumlicz T., Ubezpieczenie w polityce społecznej. Teksty i komentarze, Fundacja Instytut Zarządzania Ryzykiem Społecznym, Warszawa 2015.

Szumlicz T., Zabezpieczenie społeczne ... 50 lat później, „Ubezpieczenia Społeczne. Teoria i praktyka" 2016, nr 3.

Uścińska G., Europejskie standardy zabezpieczenia społecznego a współczesne rozwiqzania polskie, Instytut Pracy i Spraw Socjalnych, Warszawa 2005.

Uścińska G., Międzynarodowe standardy i formy współpracy w polityce społecznej oraz ich wpływ na Polskę, [w:] Polityka społeczna. Podręcznik akademicki, Firlit-Fesnak G., Szylko-Skoczny M. [red.], Wydawnictwo Naukowe PWN, Warszawa 2007.

Żukowski M., Otwarta koordynacja zabezpieczenia emerytalnego w Unii Europejskiej - nowy etap europejskiej polityki społecznej, „Polityka Społeczna” 2002, nr 11/12.

\section{Akty prawne:}

Ustawa z dnia 13 października 1998 r. o systemie ubezpieczeń społecznych (Dz. U. 1998, nr 137 poz. 887]. 


\section{Funding and compensating equivalence in the social security system - the insurance aspect}

The article presents the aspect-oriented approach to describe and clarify the social security system and the public social funds in this system. Special attention is given to the public social funds from the point of view funding and compensating equivalence. Against this background consider opportunities to be included in the social security system solution called social enhanced insurance, which is to enable the family households more easily attaining a desired level of social security through private insurance.

Keywords: social security, social public funds, funding equivalence, compensating equivalence, households insurance.

PROF. DR HAB. TADEUSZ SZUMLICZ - Katedra Ubezpieczenia Społecznego, Kolegium Ekonomiczno-Społeczne, Szkoła Główna Handlowa w Warszawie. 